\title{
KÜSIMUSE VORM, EPISTEEMILINE STAATUS JA EPISTEEMILINE HOIAK
}

\author{
TIIT HENNOSTE
}

\section{Sissejuhatus}

$\mathrm{K}$ üsimine ja vastamine on olulisemaid sotsiaalseid tegevusi inimsuhtluses. Seetõttu on seda analüüsitud erinevates keele ja suhtluse analüüsi mudelites. Keskseks probleemiks on sealjuures, millised on küsimise vahendid ja kuidas need on seotud küsimise kui sotsiaalse tegevusega (inglise keeles eri teooriates social action, speech act, dialogue act). Käesoleva töö aluseks olev mudel ja mõtteviis pärinevad USA sotsioloogilt ja vestlusanalüütikult John Heritage'ilt (vt Heritage 2010, 2012a, 2012b, ilmumas; Heritage, Raymond 2005; Raymond, Heritage 2006). Tema töö mind huvitava osa kokkuvõttena võib käsitleda aastal 2012 ilmunud artiklit „Epistemic in Action: Action Formation and Territories of Knowledge" (Heritage 2012a).

Heritage'i lähenemise taustaks on vestlusanalüütiline arusaam, et keskne keele analüüsis on sotsiaalne tegevus. Teisisõnu, meie eesmärk ei ole moodustada lauseid, vaid teha keele abil erinevaid tegevusi: küsida, tervitada, jutustada jne. Nende tegevuste vormistamine on vestluses seotud ühelt poolt suhtluse järjendilise ehitusega, teiselt poolt aga suhtlejate omavaheliste suhetega.

Heritage lähtubki oma lähenemises suhtlejate teadmistest teineteise ja maailma kohta. Suhtlejatel on üldjuhul erinev ligipääs hetkel teemaks olevale infole. Seda erinevust väljendab mõiste episteemiline staatus (epistemic status) (Heritage 2012a: 4). Heritage küsib, milline on episteemilise staatuse suhe küsimuse moodustamise vormivõtetega. Tema põhimõtteline vastus on järgmine: episteemiline staatus on küsimuse moodustamisel ülimuslik morfosüntaksi ja intonatsiooni suhtes. Just staatussuhete alusel määratlevad inimesed, kas mingit suhtlusakti antud hetkel tõlgendatakse infosoovina või infoandjana (Heritage 2012a: 3, 7, 24).

Heritage'i teine oluline mõiste on episteemiline hoiak/seisund (epistemic stance) (Heritage 2012a: 6-7). Kui episteemiline staatus on sotsiaalsete suhete suhteliselt kestev omadus (enduring feature), siis episteemiline hoiak märgib teadmiste suhete hetkeolukorda, mis muutub suhtluses voor-voorult ja mida juhitakse voorude/lausungite ehitusega (Heritage 2012a: 6). Lausungite erinev grammatiline vorm (nt Are you married? ja You're married, aren't you?) väljendab küsija erinevaid episteemilisi hoiakuid/seisundeid. ${ }^{1}$

Siinsel artiklil on kaks eesmärki. John Heritage lähtub oma analüüsides ingliskeelsest maailmast. Mu esimene eesmärk on vaadata, kas ka eesti suhtluses on suhtlejate episteemiline staatus grammatikat ületav mõjur. Teiseks huvitab mind see, milline on kas-küsimuse episteemilisi hoiakuid näitav

1 Siinses artiklis on stance tõlgitud sõnaga 'hoiak', kuid mudeli jaoks on oluline vastandus püsivama ja hetkelise seisundi vahel ning staatussuhete ja keelelise väljenduse vahel. 
vormivahendite skaala eesti keeles. Heritage'i meetodiks on kvalitatiivne vestlusanalüüs. $\mathrm{Mu}$ lähenemine erineb sellest osaliselt, sest ma proovin tuua lisaks kvantitatiivseid tõendeid. Selliselt täiendab siinne lähenemine ühtlasi Heritage'i oma.

Artikli näitematerjal pärineb Tartu Ülikooli suulise eesti keele korpusest ning kvantitatiivsete analüüside põhjaks on telefoni infodialoogides küsimustega tehtavate sotsiaalsete tegevuste analüüs artiklis „Küsimused eestikeelses infodialoogis II. Küsimused ja tegevused” (Hennoste jt ilmumas). Siinsed näited pärinevad eeskätt kas-küsimustest nagu ka Heritage’i artiklis.

\section{Küsilausung ja küsimine}

Küsimusi moodustatakse tavaliselt küsilausungiga, mille vormistamiseks on kaks vahendite põhirühma. Esimene rühm on leksikaalsed vahendid (partiklid ja küsijätkud kus, kas, ega, eksju jms), mille terminoloogia ja sisemine liigitus on eri keeltes erinev. Teiseks rühmaks on süntaktilised vahendid (inversioon), mispuhul küsimuse sõnajärg erineb väitlausungi omast. Teiselt poolt saame välja tuua küsimise kui sotsiaalse tegevuse, mille piir ei kattu teatavasti küsilausungite piiridega (siinse arutluse aluseks on Stivers, Enfield 2010: 2621).

Kõigepealt, küsimise alla ei arvata kõiki küsilausungeid. Nii jäetakse välja küsilausungid jutustuse sees otsese kõnena, küsimusenaljad, küsimuse vormis vastused, hüüatused või tegevusele kutsuvad direktiivid (Kas sa istud!).

Küsimus kui sotsiaalne tegevus on defineeritud tavaliselt infolünga täitmisena küsija teadmistes. Selleks on vajalikud kaks poolt: küsija, kel mingi teadmine puudub, ning vastaja, kellel on küsija arvates vastav teadmine olemas. See infosoov (information request) on küsimuse tuum, mis ühe kihina on küsimises mingil viisil alati olemas. Selle kõrval aga tehakse küsimuste abil suhtluses mitmeid muid tegevusi, nt algatatakse parandusi, esitatakse soove ja seisukohti jne. Neid on nimetatud perifeeriaks, kaudseteks küsimusteks, küsimise lisakihtideks jne, kuid oluline on näha, et need on suhtluses pidevalt esinevad sotsiaalsed tegevused, mitte anomaaliad (vt ka Steensig, Drew 2008). Nendest erinevad nn viktoriini- või kooliküsimused, mille puhul vastus on küsijale teada ja mis kontrollivad teadmisi. Veel kaugemale jäävad küsimused, millele vastust ei oodata ( $\mathrm{nt}$ retoorilised küsimused või omaette pomisemised: Kuhu ma selle ometi panin?). Selles artiklis analüüsin eri tüüpi vastust ootavaid küsimusi, kooliküsimused ja vastust mitteootavad jäävad kõrvale.

Uuritavad küsimused jagan alguses kaheks vastavalt sellele, kas vastuseks oodatakse infot või kinnitust. Esimesel juhul ei ole vastajal teadmist küsitava kohta ja ta ootab infot, näiteks küsides Kust ma saan osta kartulijahu? või Kas sa oled abielus? Teise rühma lähevad küsimused, mille puhul küsijal on olemas mingi teadmine küsitava kohta, ta väljendab seda oma küsimuses ning ootab sellele kinnitust, küsides nt $S a$ oled abielus, jah? Siia rühma kuulub osa kas-küsimusi. Esimest tüüpi kas-küsimusi oleme nimetanud suletud kas-küsimusteks ja teisi vastust pakkuvateks küsimusteks (Hennoste jt 2009a: 344-346). Esimese rühma vastust nimetatakse infovastuseks (affirmation) ja teist kinnituseks (confirmation). Selline eristus on toodud välja mitmetes keeltes, kuigi eri terminites. Näiteks Nijmegeni Max Plancki Psühholingvistika Instituudi küsimuste-vastuste projektis toodi sellised erinevused 
välja suhtlustegevuste liikide all, eristades ühelt poolt Infosoovi (request for information) ja teiselt poolt Kinnituse soovi (request for confirmation) ja Hinnangut (assessment) (Stivers, Enfield 2010: 2623). Kahe rühma olemasolu toetab muuhulgas see, et mõnes keeles kasutatakse kas-küsimuse infovastuseks ja kinnituseks erinevaid keelelisi vahendeid (nt soome keeles Sorjonen 2001).

Samas on ilmne, et lisaks selgelt määratletud tüüpidele on keelekasutuses alati olemas ka piirialad. Nende puhul pole tegu uurijate teadmatusega, vaid asjaoluga, et keelekasutajal on mõnikord nimelt vaja oma lausungit vormistada ebamääraselt, jätta ta piirile, vältida kindlaid valikuid (nt kasutada keelelist vormi, mis lubab vältida sina või teie valimist). See kehtib ka küsimuste puhul ja tähendab, et küsimuste kaheks jagamine on vaid uurijapoolne tehe. Tegelikus suhtluses ei ole tegu dihhotoomiaga, vaid pigem kontiinumiga.

\section{Väitlausung ja küsimine}

Lisaks spetsiifilise vormiga küsimustele on suhtluses kasutusel ka väitlausele/fraasile sarnane küsimuse vorm (declarative question), millel puuduvad küsilausungi leksikaalsed või süntaktilised tunnused. Aga kuulaja tõlgendab seda siiski küsimusena. Mille põhjal ta seda teeb?

Üks seletus on alati olnud spetsiifiline intonatsioon. Seda on uuritud eeskätt laborieksperimentides (vt ülevaatlikult Haan 2001). Eri keelte tegeliku suhtluse analüüs on näidanud siiski selle kriteeriumi problemaatilisust. Nt Plancki projekti uurimused Ameerika inglise, itaalia, taani ja hollandi keele kohta tõid välja, et küsiv intonatsioon on vaid osal küsimusena tõlgendatud väitlausungitest (Stivers 2010: 2774; Heinemann 2010: 2706; Rossano 2010: 2759-2764; Englert 2010: 2672). Lisaks osutab hollandi suhtlust analüüsinud Christina Englert (2010: 2672), et Judith Haani leitud intonatsioonierinevused ei pea spontaanses tegelikus suhtluses hästi paika.

Eesti keele spontaanse kõne lauseintonatsiooni on uuritud suhteliselt vähe (vt Asu 2002; Asu, Nolan 2003). Loetud kõnes on leitud, et jutustava lausena mõeldud väitlause intonatsioon erineb küsimusena mõeldud väitlause omast. Osal juhtudest on küsimuse fookuseks olev sõna tugevalt esile tõstetud. Osal juhtudest on lause lõpus väike tõus. Osal juhtudest saab aga öelda, et väitlausena vormistatud küsimuse ja tavalise väitlause intonatsioonikontuuride langused on erinevad. Suulise keele korpuse materjali kuulamine ja näidete pisteline analüüs näitas, et kõik toodud tüübid on tegelikus suhtluses olemas, kuid lisaks neile on lausungid, milles küsimusena tõlgendatava väitlausungi intonatsioon ei erine informeeriva väitlausungi omast. ${ }^{2}$

1. H: .hh ee tervist on see $[\mathrm{XX}]$ osakond.

2. V: [jaa=on, on, ]

3. $\mathrm{V}: \mathrm{jah}$

4. $\mathrm{H}$ : $\mathrm{mm}$.hh mul on selline probleem=et kui ma tahan: (.) nüt sel `kevadel (.) või `suvel kooli `lõpetada=et mis `tingimused sis peavad olema 'täidetud kõik.

2 Antud juhul on kõrvaga kuulamine oluline tegur, sest meie eesmärgiks on suhtlejate käitumise analüüs tegelikus suhtluses, milles nood lausungite interpreteerimisel lähtuvad oma kõrvaga kuuldust. 
5. V: 'kooli? tähendab, ‘ülikooli.=

6. $\mathrm{H}: \quad=$ ülikooli jah.

7. V: teil peab=hh kõik aine'punktid peavad olema nende: eu=hh 'erialati 'koos tähendab oma 'peaaine omad peavad koos olema ja 'kõrvalained mis teil sis 'võetud on ja noh 'üldse ka ütleme kokku see sada='kuuskend ainepunkti [noh,]

Näites 1 on H helistanud ülikooli XX osakonda. Ta alustab oma juttu küsimusega, millised tingimused peavad olema täidetud, et lõpetada. Selle juures kasutab ta sõna kooli (voor 4). See tekitab probleemi ametnikus ning too algatab voorus 5 paranduse. Alguses kordab ta sõna kooli, tehes seda tugevalt tõusva-langeva intonatsiooniga, mis viitab küsimusele ja imestamisele. Aga sellele järgnev tähendab, ülikooli on väitlausungilise intonatsiooniga. Samas ei tõlgenda $\mathrm{H}$ seda mitte fakti konstateerimisena, vaid vastust pakkuva küsimusena, mis ootab kinnitust, vastates ‘ülikooli jah (voor 6). V jätkab vastusega $\mathrm{H}$ esimesele küsimusele, näidates sellega ühtlasi, et aktsepteerib sellise tõlgenduse.

Kokkuvõttes, kuigi intonatsioon võib mängida oma rolli, ei ole ta määrav sellise lausungi küsimuseks tõlgendamisel ega anna ühest vastust, mille alusel tõlgendab partner väitlausungit küsimusena.

Suhtlusuuringutes kasutatud esmane lahendus sellele probleemile pärineb Ameerika sotsiolingvistilt William Labovilt ja terapeut David Fanshelilt, kes ehitavad lihtsa mudeli (Labov, Fanshel 1977: 100). Oletame, et on kaks kõnelejat A ja B. Sündmuste seas, millest nad räägivad, on muuhulgas selline info, mida valdab ainult $A$ ja mida $B$ ei tea (A-sündmused), ja info, mida valdab ainult B ja ei tea A (B-sündmused). Sellisel juhul kehtib kinnitusnorm (rule of confirmation): kui A esitab väite B-sündmuse kohta, siis tõlgendab B seda kui kinnitust ootavat küsimust (*Sa oled abielus? // Jah). Samas ei saa A esitada samasugust kinnitust ootavat väidet A-sündmuse kohta (*Ma ei oska sü̈̈a teha). Seega tõlgendatakse selle mudeli järgi väitvormis lausung kinnitust ootavaks küsimuseks siis, kui tegu on B-sündmusega ehk infoga, mida valdab ainult kuulaja. Näites 1 oli tegu just sellise olukorraga. Ainult $\mathrm{H}$ teadis, kas ta tahab tegelikult lõpetada ülikooli või mingit muud kooli.

See ei tähenda muidugi, et B-sündmuste ja väitvormis küsimuste piirid langeks kokku. Vastupidi, B sündmuste kohta võib küsida eri viisil. Vaatame näidet 2 , kus $\mathrm{H}$ helistab sõbrannale ja küsib peedi olemasolu kohta. Ka see on B-teave, mida valdab ainult vastaja, aga B-küsimus real 5 on vormistatud küsisõna kas abil.

1. H: tere siin Jaanika.

2. (0.5)

3. H: tead=et mul on sulle üks `palve.

4. V: noh

5. H: et kas sul on 'peeti kodus.

6. V: peeti

7. H: jah

8. V: ma `arvan küll et `peaks olema. 
Hilisemad empiirilised analüüsid eri kultuuride suhtluse kohta on selle normi toimimist kinnitanud. Nt Plancki projekti analüüsid näitasid, et küsija väitlausungi vormis küsimused käisid (peaaegu) alati B-sündmuste kohta (Stivers 2010: 2774; Heinemann 2010: 2706; Rossano 2010: 2762; Englert 2010: 2672). Ilusaks tõestuseks on sealjuures itaalia keel, milles kasutatakse kas-küsimuse moodustamiseks peaaegu ainult erinevaid intonatsioone. 12,5 protsendil näidetest ei erinenud see väitlausungi omast. Need küsimused käisid B-sündmuse kohta (Rossano 2010: 2762).

Kuidas on olukord eesti keeles? Me analüüsisime helistamisi infotelefonile (vt Hennoste jt ilmumas). Selles kogumis oli 859 küsimust, sh 169 grammatiliselt väitlausungiga vormistatud küsimust. Me ei analüüsinud läbi kõigi nende intonatsiooni, kuid suhtluse analüüs näitas, et need küsimused käisid samuti B-sündmuse kohta.

Labovi-Fansheli mudelit on aja jooksul arendatud ja modifitseeritud. Anita Pomerantz lisas sellesse eristuse esmase ja teisese teadmise vahel (first hand / second hand) ehk teadmiste vahel, mis pärinevad isiklikust kogemusest, ja nende vahel, mis on kuuldud teistelt, tuletatud arutluste abil jne. Ta näitas, et kui A esitas teisest teadmist B-le, kellel oli sama teave olemas esmasena, siis tõlgendas B seda infosoovina (Pomerantz 1980). Akio Kamio (1997) tõi sisse infoterritooriumi mõiste (territory of information), näidates, et teadmine sama asja kohta moodustab kontiinumi ehk jaguneb suhtlejate vahel suhteliselt. Ühte otsa jääb olukord, kus A-l on olemas peaaegu täielik teadmine mingi nähtuse kohta ja B-l on see peaaegu täielikult puudu, ning teise otsa olukord, milles nende teadmised on suhteliselt võrdsed. Kui A ja B jalutavad ilusa ilmaga väljas ja A ütleb B-le Ilus ilm täna, siis on nende positsioonid väga sarnased, kui aga A ütleb B-le Ma räägin sulle loo, mis minuga eile juhtus, siis markeerib see maksimaalselt kaugeid positsioone. Lisaks laiendas Kamio mõiste teadmiste olemasolult sellele, kellel on õigus vastavat asja teada ja seda välja öelda (vt ka Heritage, Raymond 2005; Raymond, Heritage 2006). Nendest alustest lähtudes ehitab oma mudeli John Heritage.

\section{John Heritage'i suhtlusmudel: episteemiline staatus ja episteemi- line hoiak}

Labovi, Pomerantzi ja Kamio ideed võtab Heritage kokku mõistega episteemiline staatus. Suhtlejatel on oma infoterritooriumid ning iga infotükk võib kuuluda kõigi suhtlejate territooriumile, kuid tavaliselt eri määral. Seda suhtlejate suhteliselt erinevat ligipääsu (ja ka õigust) mingile infoterritooriumile väljendabki mõiste episteemiline staatus (Heritage 2012a: 4). Tähtis on sealjuures see, et suhteline episteemiline staatus ei ole ühe osaleja määrata, vaid see on konsensus, mis põhineb osalejate hinnangul selle kohta, milline on nende endi ja partnerite episteemiline ligipääs ja õigus teatud infoterritooriumidele. Episteemiline konsensus on olemas, kui kõneleja ja kuulaja tõlgendavad suhtelist staatust ühtmoodi, mida näitab tavaliselt see, et nad ei tõsta seda suhtluses probleemiks.

Kuna tegu on erinevusega, siis on võimalik suhtelist ligipääsu infoterritooriumile kaaluda. Heritage kasutab siin terminit episteemiline gradient/ kalle (epistemic gradient). Info on jaotunud suhtlejate vahel nii, et neil on roh- 
kem teadja [K+] või vähem teadja [K-] positsioon (more/less knowledgeable). Nii on küsimuse esitajal vähem teadja positsioon ja vastajal rohkem teadja positsioon. Selle juures võib kalle ehk suhtlejate teadmiste kaugus üksteisest olla suurem või väiksem. Sellega seostub mõiste episteemiline hoiak/seisund, mis märgib suhtlejate (teadmiste) suhete hetkeolukorda. See suhe muutub voor-voorult ja seda juhitakse/vormistatakse voorude/lausungite ehituse abil (Heritage 2012a: 6-7). Teisisõnu, episteemiline hoiak märgib episteemilise staatuse keelelist väljendust suhtluses antud hetkel.

Heritage toob näitena inglise keele kohta lihtsad konstrueeritud lausungid, milles sama propositsiooniline sisu (abielus olemine) on esitatud kolmes erinevas grammatilises vormis: Are you married? // You're married, aren't you? // You're married (Heritage 2010: 48; 2012a: 6). Kõigis neis on tegu infoga, mis kuulub vastaja teadmiste territooriumile. Küsija on seega kõigil juhtudel vähem teadja [K-] ja vastaja enam teadja $[\mathrm{K}+]$ positsioonis. Aga samas väljendab lausungite erinev grammatiline vorm küsija erinevaid episteemilisi hoiakuid. Esimese lausungiga näitab küsija, et tal ei ole kindlat teadmist partneri abielulisuse kohta, ning väljendab selliselt oma „mitteteadja” seisundit [„unknowing” (epistemic) stance]. Teisel ja kolmandal juhul näitavad lausungid aga teatud teadmist, et partner on abielus, väljendades küsija „teadja” seisundit [,knowing” (epistemic) stance]. Mitteteadja hoiak eeldab vastuseks infot, teadja hoiak ootab kinnitust (Heritage 2012a: 6). ${ }^{3}$ Toodud mudelit illustreerib joonis 1 .

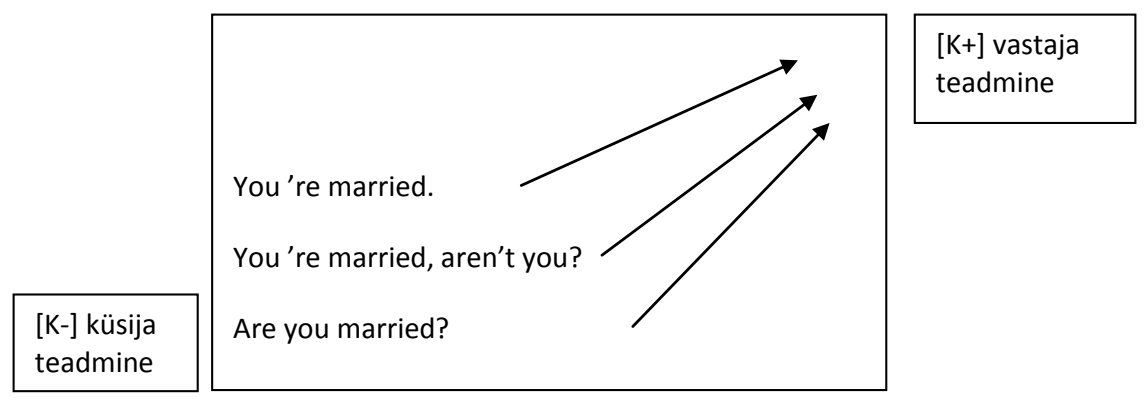

J o o n i s 1 . Küsimuste vorm ja episteemiline hoiak episteemilise kalde terminites (Heritage 2010: 49, 2012a: 7).

Episteemilise gradiendi/kalde terminites tähendab see, et esimene näide esindab tugeva kaldega suhet küsija ja retsipiendi vahel (Heritage 2012a: 6). Teine ja kolmas näide aga esindavad suhteliselt tasase kaldega suhet. Sealjuures väljendab kolmas variant väiksemat episteemilist kallet ehk võrdsemat suhet kahe poole vahel kui teine, kuna üldjuhul mitteteadjad esitavad küsimusi ja teadjad väiteid (Heritage 2012a: 7).

Seega näeme siin osalt tuttavat pilti, milles eristuvad vastuse pakkumine ja mittepakkumine ning kinnituse ja infovastuse ootamine. Aga oluline on

${ }^{3}$ Lisaks on toodud välja, et mitteteadja hoiak ootab tüüpiliselt info edasist laiendamist ja projekteerib sama suhtlusjärjendi jätkamist, samas kui teadja hoiaku väljendamine ootab pigem lihtsalt kinnitust ja suhtlusejärjendi sulgemist/lõpetamist (vt Heritage 2012a: 6 ja sealsed viited). 
see, et selles mudelis pole tegu ühepoolse otsustusega, millele viitas vastuse pakkumine, vaid partnerite suhtega. Ja teiseks, siin pole tegu vastanduse, vaid skaalaga, mis esitab kas-küsimuste vormistamise vahendeid erineva episteemilise hoiaku kaldenurga osutamiseks. Inglise keeles moodustub neist rida: sõnajärg - küsijätkud - väitlausung.

Lisaks toob Heritage välja, et eri kaldenurgaga suhte puhul pärineb teave tihti eri allikatest. Nõrga kalde puhul on vastav asi tihti juba antud vestluses kõneks olnud. Sellised on nt parandusalgatused, mille puhul küsimuse põhjustanud info on peaaegu alati vahetult küsimusele eelnevas voorus, nagu näites 1. Tugevama kalde puhul on tihti tegu teadmistega, mis pärinevad väljastpoolt antud situatsiooni või toetuvad järeldustele. Vaatame näidet 3.

1. H: e tervist. ma helistan ajalehe`kuulutuse peale.=

2. $\mathrm{V}: \quad=$ jah.

3. H: $\mathrm{e}=\mathrm{see}=\mathrm{on}($.) töö `Soomes eks.

4. V: jah jah.

5. H: ee kas: `maasikate korjamine.

6. V: ee seal on nüd üsõnaga me=me `see=aasta ei=`lähegi. me läme see=a- meil on `kõige `esimene asi see `ästi kallis `mari on 'murakas.

7. H: ahaa

/.../((79 vooru vahele jäetud $))$

8. V: [see=on] kõige `tähtsam et me saame ka `järgmine aasta neid organi seerida eelmine aasta läksime `Lätti? (.) ja oleme ka `see=aasta.

9. H: ahah .hh aga vaadake me `elame kuskil eksju,

10. (.)

12. V: [jah]

13. $\mathrm{H}: \quad$ [ja] 'korjamine toimub `metsas ma kujutan ette.=

14. V: =jah, [jah.]

15. $\mathrm{H}: \quad$ [aga] kuidas elupaigast `metsa saab.

Näites 3 helistab naine $\mathrm{H}$ ajalehe tööpakkumiskuulutuse peale. Vastaja V on töö organiseerija, kes valdab infot. Selliselt on $H$ vähem teadja ja V enam teadja staatuses. Voorus 3 esitab H küsimuse töötamise maa kohta. Ta vormistab selle vastust pakkuva küsimusena, mis viitab, et tal on teadmine selle kohta, et töö on Soomes, ja ta ootab sellele kinnitust (eks). V vastab sellele jah jah kordusega. Sellised vastused näitavad eri keeltes küsimuse teatavat endastmõistetavust või sobimatust (Heinemann 2009). H järgnev küsimus voorus 5 käib konkreetse töö kohta. See on vormistatud kas abil. Ka siin on küsijal mingi teadmine olemas (maasikate), aga ta ei paku seda välja kinnitust ootavas vormis, vaid jätab lahti ka võimaluse, et korjatakse või tehakse midagi muud, väljendades nõrka teadja hoiakut. Voorus 13 moodustab ta väitlause koos vastava intonatsiooniga, väljendades samuti tugevat teadja hoiakut. Aga vastavalt suhtlejate episteemilise staatuse suhtele ei tõlgenda V seda infona, vaid kinnitust ootava küsimusena, vastates 14 . voorus jah, jah.

Küsimused töötamise koha ja loomuse kohta voorudes 3 ja 5 toetuvad teadmisele, mis pärineb väljastpoolt antud situatsiooni (nt teadmisest, et tol ajal 
käidi tööl põhiliselt Soomes ja korjati marju). Küsimus metsa kohta (voor 13) on aga tuletatud eelnevast tekstist, milles oli juttu elukohtadest (puudub näitest) ja murakate korjamisest (voor 6).

\subsection{Episteemiline staatus ja kooskõlalised suhted}

Üldiselt proovivad suhtlejad vormistada oma voorud nii, et valitseks kooskõla neis väljendatava episteemilise hoiaku ja episteemilise staatuse vahel, mis neil on antud teema suhtes. Teiselt poolt püüavad nad hoida kooskõla oma staatuse väljendamise ja partneri staatuse vahel. Küsimuste seisukohast tähendab see, et partnerist vähem teadvad inimesed [K-] küsivad ja teadjamad $[\mathrm{K}+]$ esitavad väiteid ehk eri tüüpi infot. Ideaalis küsitakse küsilausungitega ja väidetakse väitlausungitega. Samas aga teame, et mõnigi kord tõlgendatakse väitlauseid küsimusena ja küsilausungeid väidetena. Sellest tulebki küsimus, milline on vormivõtete ja staatuse omavaheline suhe. John Heritage'i põhimõtteline väide ütleb, et suhteline episteemiline staatus on ülimuslik hoiakut väljendava morfosüntaksi ja intonatsiooni suhtes (Heritage 2012a: 3, 7, 24).

Selle väite tõestamiseks kasutab ta näiteid kas-küsimustest suhtluses. Ta toob näiteid, milles väitlausungina vormistatud voorusid tõlgendatakse informeeriva tegevusena siis, kui lausungi esitaja episteemiline staatus on partneri omast kõrgem, ja küsimusena siis, kui see on madalam. Teistpidi näitab ta, et kui lausungi ütleja episteemiline staatus on partnerist madalam, siis tõlgendab see tema küsilausungid küsimuseks, kui see aga on kõrgem, siis kõlavad tema küsilausungid partnerile kui erinevat tüüpi info pakkujad. Seega näitab ta ühtlasi, et neil juhtudel valitseb partnerite vahel konsensus teineteise suhtelise staatuse tõlgendamisel.

Vaatame sama tüüpi juhtumeid eesti suhtluses. Näites 2 nägime, kuidas küsivormis lausungit peedi kohta tõlgendati küsimusena ning partneri episteemiline staatus oli antud teema osas kõrgem kui küsimuse vormistajal. Näidetes 1 ja 3 nägime, kuidas küsimusena tõlgendati väitlausungeid, kui partneri episteemiline staatus oli kõrgem kui lausungi esitajal.

Ka ülejäänud normid leiavad eesti suhtluses järgimist. Näites 3 võime ka näha, kuidas madalama staatusega $\mathrm{H}$ tõlgendab V väitlausungitest koosnevat 8 . vooru infona. Sellele osutab asjaolu, et ta reageerib V tekstile 9. voorus ahah abil, mis on eesti keeles informeerituse muutumist osutav partikkel (vt Keevallik 1999). Näites 4 näeme, kuidas küsilausungeid ei interpreteerita mitte infosoovina, vaid infoandmisena, kui ütleja episteemiline staatus on kõrgem.

1. V: kas teil `omme `sobib.

2. H: ee `sobib `küll jah.

3. V: ee:=ütleme et=e kella `kümnest=ee=h (.) `neljani on `vaba.

4. (1.0)

5. H: õ̃ siis paneks=hh (2.0) kas kell `kaks=või, või pool `kolm=või.

6. V: $\quad \tilde{o} \tilde{o}=h h($.$) pool=`kolm jah.$

7. H: jah.

8. (.)

9. V: ee ja kuidas `nimi on. 
Selles näites on klient $\mathrm{H}$ helistanud ortopeediafirmasse jalatsite tellimiseks. Näiteosa alguseks on jõutud aja kokkuleppimise faasi. Kolmandas voorus pakub firma töötaja $\mathrm{V}$ välja ajavahemiku, millest klient peab aja valima. $\mathrm{H}$ alustab pärast pausi viiendas voorus valimist kõhklemisi (õõ, siis paneks, paus), mille järel ta ütleb kas. See võib antud positsioonis olla küsisõna või konstruktsiooni 'kas A või B' algus. Seejärel pakub ta ühe aja, lõpetades selle kokkuhääldatud või abil. Selle järel pakub ta teist aega, vormistades selle samal viisil. Tulemuseks on kahte alternatiivi sisaldav küsiv konstruktsioon, kuna sellises positsioonis ja sellise hääldusega või on eesti suhtluses üldjuhul küsisõna. V aga ei tõlgenda seda mitte küsimusena, millele tema peaks vastama, vaid ebaselgelt vormistatud infona. Seda näitab kuuendal real algatatud parandus, mille eesmärgiks on saada ühene kinnitus nimelt H-lt. H vastab küsimusele, viies paranduse läbi. Sellega osutas ta ühtlasi, et partneri tõlgendus tema lausungi kohta ei rikkunud suhtlusnormi. Antud juhul on $\mathrm{H}$ episteemiline staatus aja küsimuses $\mathrm{V}$ omast kõrgem, sest just tema valdab infot, millal ta soovib tulla, ning lisaks oli just temale antud vooruga 3 õigus otsustada kellaaja üle.

\subsection{Vastuolu suhtelise episteemilise staatuse tõlgendamisel}

Eelnevates näidetes valitses partnerite vahel konsensus teineteise suhtelise episteemilise staatuse tõlgendamisel. Lisaks on aga juhtumid, milles partnerite tõlgendus teineteise staatusest lahkneb. Vaatan siin näidet, milles kuulajapoolne küsilausungi tõlgendus lahkneb kõneleja enda omast.

Näites 5 vaidlevad $R, E$ ja $V$ tee üle. Teema algas $R$ ütlusega, et ta on kohvist tüdinud, mille peale $\mathrm{E}$ soovitas teed juua. Sellest sündis arutlus, kas kummelitee on päristee või mitte. Selle järel sekkub V, kes soovitab kanget teed (voor 1).

1. V: kanget 'teed ikkagi=nagu.

2. (0.5)

3. R: no näiteks?

4. (2.0)

5. V: Gruusia teed.

6. R: jah?

7. E: Liptun Liptun.

8. (0.8)

9. R: `noo=se `must=võ? (.) `kollane.

10. (1.0)

11. E: kollast võib `ka juua.

12. (.)

13. R: mis `vahe sel `mustal=ja kollasel=on.

14. (.)

15. E: @ maitse `vahe? @

16. (.)

17. R: 'ei=ole.

18. E: on 'küll.=

19. R: $=\{-\}=$

20. E: =oopis teine `maitse=on, `mis=sa `seletad. 
21. (1.0)

22. $\mathrm{R}: \quad$ vaevalt.

23. $(0.8)$

24. E:

ei ‘tiia sina ka midagi,

25. R:

\$ no ma ikka tean `küll. \$

26. (1.0)

27. E:

oled=sa seda `musta `joond üldse=vä.

28. R:

@ m(h)mudugi ole:n. @ naerdes

29. (.)

30. $\mathrm{E}$ :

kuna.

31. R:

32. E:

33. $(0.5)$

\$Haagel oligi üks `pakk te[da]. \$

* [ah] õige jah. *

Real 9 toob $\mathrm{R}$ sisse kaks Liptoni tee tüüpi, öeldes 'noo=se 'must=võ? (.) `kollane. E reageerib sellele real 11 hinnanguga kollast võib `ka juua. Selle järel vormistab $\mathrm{R}$ järgmises voorus küsilausungi mis `vahe sel `mustal=ja kollasel=on. E reageerib sellele nagu küsimusele ja vastab maitse vahe. Kui $\mathrm{R}$ oleks mõelnud oma lauset infolünka täitva küsimusena, siis oleks $\mathrm{E}$ vastus olnud tema jaoks uus info ning ta oleks võinud reageerida nt ahah / ahhaa abil. Kui tegu oleks olnud vale vastusega (nt R-i jaoks oleks erinevus olnud lõhnas), siis oleks ta ilmselt selle esile toonud. $R$ aga asub E-le vastu vaidlema, öeldes real 17 `ei=ole. Nii esitab R ennast vähemalt E-ga võrdse teadja positsioonis. E seab R-i pakutud positsiooni kahtluse alla, mida näitab küsimus real 27 oled=sa seda `musta `joond üldse=vä. $\mathrm{R}$ vastab jaatavalt ning real 31 lisab nende ühisesse teadmisesse kuuluva koha, kus ta on seda teed joonud (Haagel). See on E jaoks veenev argument, mida ta tunnistab real 32. See tähendab ühtlasi, et $\mathrm{E}$ tunnistab, et R-il on teadmine teede erinevusest.

See järjend näitab, et E tõlgendas R-i küsilauset real 13, lähtudes sellest, et $\mathrm{R}$-i episteemiline staatus tee erinevuste osas on temast madalam. Järgnev vaidlus aga näitas, et $E$ tõlgendus $R$-i episteemilisest staatusest oli väär. $R$ ei tõlgendanud enda staatust madalamana ning tema küsilausung oli mõeldud pigem seisukohana, et kahel teel ei ole vahet.

\subsection{Erineva episteemilise hoiaku väljendamine eesti kas-küsimustes}

Järgnevalt tuleme näidete juurde, mida Heritage kirjeldas abieluküsimuste abil. Selles oli küsija staatus kõigil juhtudel vastaja omast madalam, sest info kuulus viimase territooriumile. Samas aga väljendas küsimuse erinev vorm infojaotuse erinevat kallet. Heritage seda teemat edasi ei arenda. Järgnevas vaatan seda probleemi kahest küljest. Esimene küsimus on, milline on eesti kas-küsimuste vormivahendite skaala erineva kaldega episteemiliste suhete väljendamiseks? Teine küsimus on, kas ka episteemiliste hoiakute väljendamise eri variantide puhul oodatakse konsensust suhtlejatevaheliste suhete väljendamisel?

Eesti keeles on nagu inglise keeleski kas-küsimuste vormistamiseks kasutusel sõnajärg, väitlausungid ning lausungi lõppu paigutuvad partiklid ja küsijätkud (või, jah, eksju jm). Aga lisaks on eesti keeles ka lausungi algusesse kuuluvad partiklid kas ja ega. Teisalt on eesti keeles vormivahendite kasutusstatistika inglise keelest erinev. Analüüsitud eesti materjalis andsid 
küsisõnad $58 \%$, väitvorm $32 \%$ ning sõnajärg $8 \%$ küsimustest. Inglise keeles olid samade vahendite protsendid 6, 31 ja 63 (Hennoste jt ilmumas).

Kui konstrueerime Heritage'i küsimused eesti keeles, võime öelda, et maksimaalset mitteteadja hoiakut väljendab oletatavasti küsimus Kas sa oled abielus? ning tugevaimat teadja hoiakut Sa oled abielus? Aga nende vahele jääv ala on heterogeenne. Me võime küsida Kas sa oled abielus või?, Oled sa abielus?, Oled sa abielus või?, Sa oled abielus või?, Sa oled abielus, eks?, Oled sa abielus, jah?, Sa oled abielus, jah? Jne.

Milline võiks olla eesti vahendite põhiskaala? Ühe vastuse pakub siin vahendite kasutuse sagedus, mis pärineb infodialoogide analüüsist (Hennoste jt ilmumas). Selles analüüsis jagasime kas-küsimused suletud, vastust pakkuvateks ja jutustavateks kas-küsimusteks (neile vastati nagu eriküsimusele ja nende puhul ei arvestatud suletust ega vastuse pakkumist). Seega paigutati iga küsimus analüüsides kindlasse rühma, vaatamata sellele, kas tegu oli n-ö kindla hoiakuga või pigem piiripealse juhtumiga. Käesoleva analüüsi jaoks jagasin küsimused ümber, paigutades jutustavad kas-küsimused suletud või vastust pakkuvate küsimuste alla vastavalt nende loomusele. Tulemuseks on kaks küsimusterühma, milles mõlemas kasutatakse mitmeid erinevaid vormivahendeid. Praegu toon välja ainult sagedased keelevahendid ( $k a s$, $k a s+v \tilde{o} i$, või, jah, väitlausung, sõnajärg; vt tabelit 1).4

Tabel 1 .

\section{Sagedased kas-küsimuse vormivahendid suletud ja vastust pakkuvates küsimustes eesti infodialoogides}

$\begin{array}{lcccccc} & k a s & k a s+v \tilde{o} i & v \tilde{o} i & j a h & \text { Väitvorm } & \text { Sõnajärg } \\ \begin{array}{l}\text { Suletud küsimus } \\ \begin{array}{l}\text { Vastust pakkuv } \\ \text { küsimus }\end{array}\end{array} & 124 & 23 & 13 & - & 17 & 36 \\ & 2 & 1 & 30 & 82 & 152 & 8\end{array}$

Tabel 1 näitab, et kas ning kas+või on peaaegu ainult suletud küsimusi vormistavad küsisõnad. Episteemia terminoloogias väljendatakse nende abil tugevalt mitteteadja hoiakut. jah on ainult vastust pakkuvaid küsimusi moodustav ehk nõrgalt mitteteadja hoiakut väljendav sõna ning või jääb nende vahele. Olulisem on aga see, et eesti keele kesksed leksikaalsed vahendid moodustavad statistiliselt read, milles vahendid on komplementaarsetes suhetes: vahendid, mille kasutus ühes rühmas kasvab, teises rühmas kahaneb.

Nagu varem näidatud, esindab väitlausung maksimaalselt tasast episteemilist kallet. Seda toetab hästi ka statistika, milles vastust pakkuvate küsimuste esitamisel on väitlausung keskne vahend ning suletud küsimuste puhul jääb skaala alumisse otsa.

Kokkuvõttes võime sõnastada kvantitatiivsete andmete alusel eesti keeles teadja/mitteteadja hoiakut/seisundit väljendava kas-küsimuste vormistamise skaala: $k a s-k a s+v \tilde{o} i-v \tilde{o} i-j a h$ - väitlausung. kas abil vormistatakse küsimusi, mis markeerivad maksimaalselt mitteteadja hoiakut ehk maksi-

4 Suhteliselt sage oli ka ega, millest kuulus suletud rühma 12 ja vastust pakkuvasse rühma kolm küsimust. Jätan edasises ega kõrvale, sest ta vormistab spetsiifiliselt eitavaid küsimusi. 
maalselt erinevate teadmistega küsijat ja vastajat ehk maksimaalset episteemilist kallet, ning väitlausungi abil küsimusi, mis osutavad vastajale maksimaalselt lähedast hoiakut ehk maksimaalselt võrdsete teadmistega küsijat ja vastajat ehk maksimaalselt tasast kallet.

Sõnajärg seostub eesti suhtluses pigem mitteteadja hoiakuga, olles suletud küsimustes kas järel sageduselt teiseks vahendiks ning jäädes vastust pakkuva küsimuse puhul statistiliselt skaala alumisse otsa. Samas on tema koht ikkagi ebamäärane. Võib pakkuda, et ta kuulub kas+või ümbruskonda. Lisaks on näha, et tegelikus suhtluses valitsevad skaala otsad, mida kasutatakse oluliselt rohkem kui vahepealseid variante.

Nii võime näha siin osalt analoogiat inglise keele skaalaga. Teadjamas otsas on väitlausung ning küsijätkud (on lihtne näha, et statistiliselt haruldased küsijätkud eksole, eks jms kuuluvad jah lähikonda). Samas aga on oluline erinevus selles, et maksimaalset mitteteadja hoiakut esindab eesti keeles kas lausungi alguses ning sõnajärg jääb veidi ebamäärasesse positsiooni.

Lähtudes leitud vormi ja hoiaku suhetest, võime seega välja tuua, et näites 3 positsioneeris küsija ennast eri küsimuste vormistamisel erinevalt. Voorus 5 vormistas ta küsimuse kas abil, osutades suurt erinevust tema ja küsija teadmiste vahel. Voorus 3 osutas ta suhteliselt võrdset teadmiste suhet ning voorus 13 väitlausungi abil maksimaalselt võrdset suhet partneriga.

Nüüd tulen küsimuste abil tehtavate sotsiaalsete tegevuste juurde. Me tõime oma analüüsis välja küsimustega tehtavad sotsiaalsed tegevused, lähtudes Plancki instituudi küsimuste projektist ja meie enda dialoogiaktide tüpoloogiast (Hennoste jt ilmumas; Stivers, Enfield 2010: 2623; Hennoste, Rääbis 2004: 52, 56-113, 121-122, 154-157). Antud juhul huvitavad mind kolm tegevust: Infosoov, kas-küsimusega tehtavad Parandusalgatused ja Kinnituse soov.

Infosoov on defineeritud selles tüpoloogias kui infovastust ootav küsimus. Heritage'i terminoloogias on tegu tugevalt kaldu suhtega. Ülejäänud tegevused olid defineeritud kui kinnitust ootavad kas-küsimused. Kas-parandusalgatus jagunes kaheks: üleküsimine, milles korratakse eelmise vooru probleemset osa, ning tõlgendusettepanek, milles pakutakse omapoolne tõlgendus probleemsest lausungist. Kinnituse soovi alla läksid kinnitust ootavad kasküsimused, mis ei olnud Parandusalgatused.

Kinnitust ootavad tegevused esindavad suhteliselt suurt küsija ning vastaja vahelist hoiakute lähedust. Aga ma oletan, et see lähedus on vähemalt veidi erinev. Kõige lähemal on partnerite seisundid üleküsimise puhul, sest siin on tegu lihtsalt teise poole esitatu (osalise) kordamisega. Selline on üleküsimine peeti näite 2 kuuendas voorus. Tõlgendusettepanek viitab suuremale kaugusele, sest sel juhul esitab küsija omapoolse tõlgenduse, mis võib olla partneri mõttele rohkem või vähem vastav. Selline oli tähendab, “ülikooli näite 1 viiendas voorus. Kinnituse soovi puhul on kalle eeldatavasti veel suurem. Põhjuseks on asjaolu, et Parandusalgatuse puhul pärineb küsimuse all olev info peaaegu alati vahetult eelnevast voorust (nagu ka näidetes 1 ja 2). Kinnituse soovi puhul võib see pärineda eri kohtadest. Mõnikord pärineb see samast dialoogist, mõnikord küsija tehtud järeldustest, mõnikord maailmateadmisest. Neid illustreerib näide 3 .

Kokkuvõttes võib oletada, et need tegevused esindavad nelja erineva kaldenurgaga episteemiliste hoiakute suhet järjekorras infosoov - kinnituse soov - tõlgendusettepanek - üleküsimine. Selle juures on tähtis, et ma läh- 
tun nimelt tegevustest, mitte vormist. Sama tegevus on väljendatav eri vormidega. Kui oletus klapib, siis peaks see peegelduma küsimuse moodustamise vahendite kasutuse statistikas.

Tabel 2 esitab küsimuste vormid, mida kasutati vastavate tegevuste moodustamiseks analüüsitud infodialoogides. See ei paku küll suuri arve, kuid siiski on näha, et infosoovi puhul valitseb suurt mitteteadmist osutav kas ning muude vahendite kasutus väheneb üldise skaalaga korrelatsioonis. Ka näeme, kuidas erinevad kolme teadjamat hoiakut väljendava tegevuse vormide protsendid. Oletatavasti sügavaima kaldega Kinnituse soovi puhul on või sagedus suurem ning väitlausungi sagedus väiksem kui Parandusalgatustes. Samuti erinevad omavahel tõlgendusettepaneku ja üleküsimise vahendid, eriti väitlausungi kasutuse osas. jah on aga üllatavalt väga ühtlane. Nii võime öelda, et tegevuste vormistamise statistika toetab toodud hüpoteesi ja kinnitab üldist skaalat.

Ta bel 2.

Kas-küsimuse moodustamise vahendite kasutussagedus
kolmes sotsiaalse tegevuse rühmas eesti infodialoogides

\begin{tabular}{|c|c|c|c|c|c|c|c|c|}
\hline Vorm & Info & $\%$ & Kinnitus & $\%$ & Tõlgendus & $\%$ & Üleküsimine & $\%$ \\
\hline kas & 60 & 54 & - & - & - & - & - & - \\
\hline kas+või & 14 & 13 & - & - & 1 & 2 & - & - \\
\hline või & 5 & 4 & 13 & 19 & 4 & 9 & 9 & 7 \\
\hline $\begin{array}{l}\text { jah } \\
\text { väit- }\end{array}$ & - & - & 18 & 27 & 11 & 25 & 31 & 24 \\
\hline lausung & 13 & 12 & 29 & 43 & 22 & 50 & 80 & 63 \\
\hline $\begin{array}{l}\text { sõnajärg } \\
\text { muud }\end{array}$ & 10 & 9 & - & - & 3 & 7 & 3 & 2 \\
\hline vahendid & 9 & 8 & 7 & 9 & 2 & 4 & 4 & 3 \\
\hline Kokku & 111 & & 67 & & 43 & & 127 & \\
\hline
\end{tabular}

\subsection{Episteemiline hoiak ja kooskõlalised suhted}

Eelnevas tõin kvantitatiivseid tõendeid selle kohta, milline võiks olla eesti keeles erinevate episteemiliste hoiakute väljendamise vahendite rida. Sellega seoses kerkib küsimus, kas vahendite valik peab olema kooskõlas tegelike teadmiste suhetega partnerite vahel? Mis juhtub, kui see valik ei ole kooskõlas?

Seda, et valik on üldjoontes kooskõlas, näitavad hästi olukorrad, milles suhtlejate episteemilised hoiakud sama teabe suhtes muutuvad suhtluse käigus voor-voorult. Sel juhul võib oodata, et seda muutust väljendatakse ka küsimuse erineva vormiga, mis sobib antud hetke uue seisundiga. Seda kinnitab hästi parandusalgatuste vorm. Paranduse tüüpiline olukord on selline, kus A on esitanud mingi B jaoks uue info, B aga algatab selle info kohta paranduse. Seega on tegu olukorraga, kus esimese info mõjul on B informeeritus muutunud ning on antud teema osas lähedane A omale. Nagu näeme tabelist 2, moodustatakse üleküsimised $87 \%$ ja tõlgendusettepanekud $75 \%$ juhtudest jah või väitvormi abil, mis mõlemad näitavad väga suurt lähedust. 
Teiseks, eelnevas oli implitsiitselt lähtutud lausungist kui valmis produktist. Kuid suuline ja kirjalik lausung erinevad põhimõtteliselt ühes asjas. Kirjutaja võib oma lausungit arvutiekraanil või paberil mitu korda ringi teha, kuid lugejani jõuab tavaliselt vaid viimane variant. Kui aga kõneleja teeb oma lausungi pärast väljaütlemist ringi, siis jõuavad kuulajani kõik erinevad variandid. Nii väljendub lausungi ümbertegemise protsess osaliselt teksti pinnal, moodustades seal erinevaid eneseparanduse variante või protsessuaalseid lausungeid, milles n-ö algus ja lõpp ei lähe hästi kokku (vt eesti keele kohta Hennoste 2008, 2011).

Seetõttu leiab suulistes tekstides ka erinevaid küsimuste muutmisi sama vooru ja sama lausungi piires. Kõneleja võib nt muuta avatud küsimuse vastust pakkuvaks kas-küsimuseks (kuhu sa 'ise tahtsid minna, 'Tartusse). Ta võib vormistada ega küsimuse ümber onju küsimuseks (e ega mingit 'pikka numbrit ei 'olegi et see'sama 'ongi onju). Ta võib küsimuse vormi ka mitu korda muuta (kas midagi ette vaja veel 'seitset või .hh või või mida). Siin alustatakse kas-vormiga, minnakse üle vastuse pakkumisele (seitset) ja lõpetatakse eriküsimusega mida.

Seega on selge, et kõneleja saab muuta ka oma episteemilise hoiaku väljendust küsimuse tegemise käigus ( $k a s>e k s o l e, k a s>$ jah vms). See omakorda lubab tuua välja juhtumid, milles inimene muudab oma väljenduse lausungi tegemise käigus sobivamaks antud hetke episteemilise seisundiga. Vaatame näidet 6.5

1. V: .hh et näiteks ommikul minna `Helsingisse .hh ja õhtul (.) kell `viis (.) läheb=e Helsingist edasi ästi luksuslikud laevad .hh ee Stokholmi, (.) ee

2. $\mathrm{H}:$ jaa?

3. V: seal=on võimalik Stokholmis sis päev=otsa `seal olla,

4. $\mathrm{H}: \mathrm{mhmh}$

5. V: ja=sis uuesti: Helsingisse `tagasi ja Helsingist `Tallinasse.

6. H: mhmh. (.) ja kas see `laev=sis sõidab nagu eksole `öösel ilmselt

7. V: jah. ta läheb õhtul välja ommikul on: ee `Stokholmis.

Selles näites kõnelevad reisibüroo ametnik V ja klient H. Jutu teemaks on võimalikud reisivariandid Stockholmi. Esimeses voorus on V esitanud info selle kohta, et laev Stockholmi läheb õhtul, ning kolmandas voorus lisanud, et nii saab terve päeva Stockholmis olla. Selle info põhjal saab järeldada, et laev sõidab õhtul ja öösel ning on hiljemalt hommikuks kohal. Selle järel alustab H küsimust laeva sõiduaja kohta kuuendas voorus kas abil. Ta jätkab kuni verbini sujuvalt ning seejärel, enne fookuseks olevat sõna öösel, vormistab küsimuse eksole abil ringi. kas-vormiline küsimus oleks antud juhul väljendanud tugevalt mitteteadja hoiakut, variant eksole öösel esindab hoiakut, mis viitab partnerile lähedastele teadmistele. Kuna küsimuse vooruks olid H teadmised laeva sõidugraafiku kohta vastaja omadele lähedal, siis oleks mak-

5 Sellist tüüpi näiteid Heritage ei analüüsi. Ta viitab aga Charles Goodwinile (1979), kes on vaadanud juhtumit, milles kõneleja muudab lausungit moodustades oma vooru adressaati ja vastavalt sellele muudab ka lausungi vormi episteemiliselt sobivaks uue adressaadiga, kes on esitatava info suhtes temaga teistsugustes suhetes. 
simaalset kaugust markeeriv kas-vorm antud situatsioonis ebasobiv. Nii on antud näitest näha, et $\mathrm{H}$ muutis oma küsimuse vormi antud hetke episteemilise seisundiga sobivamaks.

Põhimõtteliselt on võimalik ka vastupidine suund, liikumine samas lausungi teadjamast vähem teadja hoiaku suunas. Kui kõneleja soovib väljendada teadja hoiakut, siis peab ta alustama väitlausungi vormis, ilma lausungialguliste küsisõnade ja inversioonita. Tal on võimalik tuua millalgi sisse küsimust markeeriv intonatsioon ning lõpus küsijätkud, mis võimaldavad teadja hoiakut madaldada (jah, eksole, eks, või jt). Sellised näited on korpuses väga harvad.

1. H: mina külastasingi: (.) 'V- Välke.

2. V: jah.

3. $\mathrm{H}$ : kahe 'Timmoga.

4. V: 'kahega=või.

5. H: kahega `jah.

6. V: a neid pidi olema oma ma=i=tea, (.) 'kaheksa=või.

7. H: `kaheksa pidi `olema=aga .hh ma lihtsalt `üksinda tulin \{sält\} 'Luunjast=ja [ma=i]=sand nagu ülejäänusid `võtta.

9. V: [aa]

Näites 7 kõnelevad kaks inimest telefonis ühiste tuttavate külastamisest. V on varem öelnud, et ta kuulis, et $\mathrm{H}$ külastas Välke. Peale H infot selle kohta, et ta külastas Välke kahe Timmoga, algatab V real 4 paranduse `kahega=või. Saanud kinnitava vastuse, alustab ta 6 . real oma lausungit kontrasti osutava sõnaga $a(=a g a)$ ning takerdub enne arvu ütlemist, öeldes $m a=i=t e a$. Seejärel pakub ta omalt poolt numbri kaheksa ning vormistab seejärel oma väitlausungi või-küsilausungiks. Ka väitlausungi vorm oleks antud juhul tähendanud küsimust. Seda osutavad teadmiste ebakindlust markeerivad sõnad pidi olema ja oma juba enne takerdumist ning asjaolu, et see lausung jätkab sama parandusjärjendit, mille eelmises voorus $\mathrm{H}$ poolt esitatud lahendus V-d ei rahuldanud. Nii võib antud juhul suure tõenäosusega väita, et siin ei muudetud väidet küsimuseks, vaid tehti tugevam hoiak nõrgemaks.

Eelnevad näited toovad lisaks välja episteemilise hoiaku väljendamise seisukohast väga olulise asja. Nimelt paikneb maksimaalset mitteteadja hoiakut väljendav kas eesti keeles küsimuse alguses. Samuti tuleb lausungi alguses sisse tuua ka teised tugevalt mitteteadja hoiakuga seostuvad vahendid, ega ja inversioon (on teil midagi `sellist). Samas aga teadjamat hoiakut väljendavad vahendid paiknevad lausungi lõpus (jah, eksole jms). Sama jaotus kehtib ka inglise keele puhul, kus teadjamat hoiakut vormistavad küsijätkud ning maksimaalset mitteteadja hoiakut inversioon.

Selline vahendite jaotus paneb omad piirangud episteemilise hoiaku väljendamisele ja muutmisele. Kõneleja, kes soovib väljendada võimalikult mitteteadja hoiakut, peab selle valima kohe küsimuse vormistamise alguses. Kuna aga teadjama hoiaku väljendamise vahendid on lausungi lõpus, siis lubab see kergesti muuta hoiakut teadjamaks. Sealjuures saab liikuda peaaegu maksimaalset lähedust märkiva jah-ini (H: ee kas te `oskate öelda, millal ¡jalanõusid saab ‘tellida. / (0.8) / V: ee tähendab ee kas `lapsele jah? / H: jah). 
Samas aga vastupidine liikumine on oluliselt erinev. Esiteks, see muutus ei vii lähedasest hoiakust maksimaalselt mitteteadja hoiakuni, vaid liigutab hoiaku väljendust ainult teatud piirini, mida eesti keeles võikski markeerida $v \tilde{o} i / v \ddot{a}$. Teiseks on erinevus vahendite tõlgendatavuses. Kui kas-alguse puhul oli tulemuseks kergesti mõistetav keeleline erinevus, siis väitlausungiga alustamise puhul on palju raskem näha, millal on tegu algusest peale plaanitud küsijätkuga ja millal seisundi väljenduse muutmisega. Nii on need kaks võimalust ebasümmeetrilised. See ebasümmeetria on minu arvates suhtluse jaoks väga oluline asi, tuues välja mitteteadja hoiaku ja lausungi alguse fundamentaalsuse kogu küsimise protsessis.

\subsection{Vastuolu kalde sügavuse tõlgendamisel}

Näites 5 nägime, kuidas partneri ja enda staatuse suhte väär tõlgendus toob kaasa küsilausungi väära tõlgenduse ning selle kaudu suhtlushäired. Selle põhjal tuleb küsida, kas ka antud hetke teadmiste suhetega sobimatu küsimuse vorm ehk hoiak võib tekitada analoogilisi probleeme.

Sisult sama küsimust samas positsioonis võidakse vormistada erinevalt, kusjuures see erinevus väljendab erinevaid episteemilisi hoiakuid. Näidetes 8 ja 9 esitavad reisibüroo kliendid suhtluse alguses küsimuse selle kohta, kas firma korraldab suusareise. Näites 8 vormistab klient selle väitlausena (te korraldate suusa'reise), näites 9 aga kas abil (kas te: korraldate suusa'reise).

(8)

1. $\mathrm{V}:$ tere

2. H: ee (.) te 'korraldate suusa`reise.

3. $\mathrm{V}$ : jaa?

4. H: e kus'kohta te neid (.) 'korraldate.=

(9)

1. K: tere=päävast

2. (0.3)

3. T: tere?

4. (0.5)

5. K: $\mathrm{mm}$ mul on seline `küsimus kas te: `korraldate suusa`reise

6. (0.8)

7. T: ä jaa ikka?

8. (0.6)

9. $\mathrm{K}: \mathrm{mis}$

10. T: kuhu teid 'huvitab näiteks? meil on pakkuda: Slo`vakkia? (.) 'Tatrad? .hh või sis `Rootsis `Oore suusapiirkond? (.) või siis 'Alpid?`Austrias?

Esimesel juhul vastab ametnik lihtsalt jaa, osutades sellega, et küsimuse sisu ja vorm ei tekita tema jaoks probleeme. Teisel juhul aga reageerib vastaja teisiti. Alguses peab ta pausi, mis küsimuse järel viitab üldjuhul mingile probleemile vastamisel. Vastus ise koosneb sõnast jaa, millele on lisatud $i k k a$. ikka on sõna, mille tähendus on 'loomulikult, muidugi'. Vastuses osutab see, et küsitud info on kehtiv, kuid endastmõistetav ja peaks olema üldiselt teada. Seega võib see näidata, et küsimus kui selline on ebakohane või polnud see kõige paremini formuleeritud (Keevallik 2009: 45-46). 
Mõlemas näites oli vastaja episteemiline staatus kõrgem, just tema valdas infot. Seega küsimus kui selline ei ole ebakohane. Erinevad reageeringud eri vormis küsimustele osutavad, et probleem on pigem vormistuses. Antud juhul väljendavad kaks vormi selgelt erinevaid episteemilisi hoiakuid. Vormistus, mis osutas suhtlejate teadmiste maksimaalset lähedust, ei tekitanud probleeme, samal ajal kui maksimaalse mitteteadja hoiaku väljendamine kas abil tekitas probleemi. Seega võime öelda, et ikka osutas sellele, et vastaja tõlgendas enda ja küsija episteemiliste hoiakute suhet küsijast erinevalt ning tema jaoks oli suure erinevuse osutamine väär.

Situatsioon võib olla ka keerukam. Vaatame näiteid 10-12, milles infotelefoni vastajad (V-d) esitavad küsimuse, millise paiga kohta helistajad (H-d) infot soovivad (küsimus selle kohta, mis linnast partner helistab, tähendab sama). Ka siin on kõigil juhtudel H-de episteemiline staatus kõrgem, just nemad teavad, millise linna kohta nad infot soovivad.

1. H: tere. .h ee `palun kas te oskaksite `öelda kust võiks osta ’porolooni.

2. V: ja: mis 'linnast soovite

3. $\mathrm{H}:$ Tartust=[vabandust]

Näites 10 vormistab $\mathrm{V}$ eriküsimuse, mis näitab väga suurt teadmiste vahet $H$-ga. $H$ vastab koos vabandusega, osutades, et tema tegi vea, jättes linna ütlemata (tavaline on, et helistajad ütlevad linna nime, mille kohta nad infot soovivad). Sellega osutab ta ühtlasi, et partneri küsimus ja selle vorm oli õigustatud. Lisaks on korpuses samasuguseid küsimusi, millele vastatakse lihtsalt kohanimega. Seega toovad need näited välja, et suur episteemiline kalle on antud juhul õigustatud ja suhtlejates probleeme ei tekita.

1. H: tere kas=te `oskate =mulle öelda: ö (.) turismi: (0.5) ää info 'numbreid=või

2. V: Tartus.

3. $\mathrm{H}:$ jah.

1. H: tere `päevast. ma sooviks `liiklus`politsei telefoninumbrit.

2. V: jaa? soovite 'Tartust.

3. H: jaa jaa

Näidetes 11 ja 12 aga vormistavad V-d samad küsimused vastuse pakkumise abil, ühel juhul väitvormi, teisel juhul inversiooniga. Näites 11 vastab H lühidalt, osutades seega küsimuse ja selle vormi sobivust. Aga H näites 12 vastab küsimusele kordusega jaa jaa. Sellised vastused näitavad eri keeltes küsimuse endastmõistetavust või sobimatust (Heinemann 2009).

Seega näeme, et osa telefonivastajaist vormistab oma küsimuse väga madala teadmisena, teine osa aga sama küsimuse väga kõrge teadmisena. Osa helistajaist tõlgendab loomulikuna suurt teadmiste erinevust, osa väikest erinevust ja osa tõlgendab isegi vastust pakkuvat küsimust ebakohasena. Kuidas seda varieeruvust seletada? 
Kõigepealt, helistaja telefoni asukohta saab infotelefoni vastaja kindlaks teha, juhul kui tegu on lauatelefoniga ning ta näeb selle numbrit. Et helistajad küsivad peaaegu alati infot sama koha kohta, kust nad helistavad, siis on selle põhjal võimalik prognoosida hästi ka küsitavat kohta. Kui on tegu mobiiliga või vastaja numbrit ei näe, siis ta ka kohta prognoosida ei saa. Teiseks võib prognoosida helistamise kohta, juhul kui vastajafirma asub kindlas linnas, nt Tartus või Pärnus. Sel juhul helistavad sellele telefonile üldjuhul sama linna inimesed. Kui aga on tegu firmaga, mille vastajad on koondatud ühte linna, siis seda tegurit prognoosimisel kasutada ei saa. Seega võib vastaja teada või suuta hästi prognoosida helistaja asukohta ja võib ka üldse mitte teada. Vastavalt sellele saab ta vormistada oma küsimuse, osutades helistajale lähedast või kauget teadmist.

Helistaja võib mõelda kahel viisil. Näidetest paistab, et põhiliselt lähtub ta sellest, et vastaja ei tea, millise linna kohta ta küsida kavatseb. Aga ta võib ka mõelda, et vastaja istub samas linnas, kust ta helistab. Sel juhul võib ta pidada kohaküsimust endastmõistetavaks.

Seega saame kokkuvõttes öelda, et kõnelejad vormistavad oma küsimused vastavuses antud hetke episteemilise seisundiga ning korrigeerivad väljendusvormi vajadusel ka sama lausungi piires (näited 6 ja 7). Vastuolu suhtlejate vahel episteemilise hoiaku kaldenurga tõlgendamises toob kaasa häireid suhtluses samamoodi nagu vastuolu teineteise episteemilise staatuse tõlgendamises (näited 9 ja 12). Samal ajal on olukordi, millesse sobivad erinevad episteemilised hoiakud (näited 10 ja 11). Nende puhul võib olla tegu sellega, et ühelt poolt on olukorrad tegelikult mingi info valdamise osas erinevad ning teiselt poolt võimaldavad sarnased olukorrad suhtlejate jaoks erinevaid tõlgendusi.

\section{Kokkuvõtte asemel}

Käesolev artikkel andis kõigepealt ülevaate suuliste suhtlejate suhtelise episteemilise staatuse ja lausungite vormi vahekorrast. Lähtekohaks oli John Heritage'i põhimõtteline väide, et suhtlejate suhteline episteemiline staatus on ülimuslik morfosüntaksi ja intonatsiooni osas. Just staatus on see, mis määrab lõppkokkuvõttes, kas antud lausungit tõlgendatakse info küsimisena või info andmisena. Artiklis nägime, et episteemilise staatuse ülimuslikkust saab näidata ka eesti suhtluses.

Teiseks vaatasime episteemilist hoiakut/seisundit, mis märgib suhtlejate (teadmiste) suhete hetkeolukorda, mis muutub voor-voorult ja mida juhitakse lausungite ehituse abil. Siin tõime kõigepealt välja põhilised vahendid, mille abil vormistatakse erinevaid hoiakuid eesti kas-küsimustes. Teiseks näitas analüüs, et kõneleja valib vahendid, mis sobivad hetkel tema hoiakuga. Seda tõestas asjaolu, et kõneleja muudab vajadusel oma seisundit/hoiakut väljendavaid vahendeid lausungi tegemise käigus, et viia valmis küsimus kooskõlla seisundiga. Samuti tõestas seda asjaolu, et vastuolu kõneleja ja kuulaja arusaamades episteemilistest seisunditest ning sellest johtuv ebasobiv vahendite valik võib viia probleemideni suhtluses. Samas aga tuli ka välja, et teatud olukordades on hoiakute valik suhteliselt vaba.

On selge, et siinne pilt on vaid osaline ja esmane. 
Kõigepealt, kõik siin käsitletud teemad vajavad põhjalikumat analüüsi eesti materjalil. Praegu vaatasin kvalitatiivselt ainult näiteid, milles esinesid kas-jah, kas-eksole, kas-väitlausung ehk skaala otsad. Eraldi analüüsi vajab vahepealsete vahendite kasutus (või, kas+või). Eraldi tuleks uurida, kas statistiliselt haruldased küsijätkud (eksju, eks jt) kuuluvad jah-ist alla- või ülespoole. Samuti tuleb analüüsida ega ja sõnajärje täpsemat positsiooni vahendite skaalal. Praegu ei eristanud ma omavahel eri intonatsioonikontuuriga väitlausungeid. Ja tegelikult ei ole selge, kas peenemat skaalat on üldse võimalik välja tuua või on osa vahendeid n-ö samal positsioonil, erinedes hoopis mingite spetsiifiliste tunnuste ja rollide poolest. Lisaks, see lähenemine vaatas ainult küsimuste vormistamise keskseid ja n-ö spetsiifilisi vahendeid. Lausungites on ka muid märke, mis osutavad küsimusele (nagu ebakindlust märkivad sõnad). Oluline on vaadata nende seoseid selle maailmaga.

Teiseks vajab uurimist episteemilise seisundi markeerimine laiemalt. Seda ei muudeta ainult sama lausungi piires, vaid ka näiteks pärast lausungi lõppu, vooru üleminekualas. Samuti on huvitav vaadata, kuidas seostub episteemilise seisundiga küsimuse vormi muutmine peale vastaja pausi.

Kolmandaks on oluline uurida, millised kaheosalised küsivormid on grammatikaliseerunud ja millised mitte ning kas grammatikaliseerunud vormis (nt $k a s+v \tilde{o} i)$ on alati tegu kaheosalise vormiga või mõnikord ka seisundi muutumise markeriga.

Neljandaks, siin oli juttu üksnes episteemilise staatuse ühest küljest. Kõrvale jäid teemad, mis seostuvad esmase ja teisese infoga ning suhtlejate õigustega infot omada ja väljendada.

Viiendaks, siin antud pilt vaatas episteemilist staatust Heritage'i järgi suhteliselt ühedimensioonilisena. Samas on see pigem multidimensiooniline maastik (vt Sidnell 2012: 55 ja sealsed viited). Sellega seoses võib eri inimestel olla ligipääs samale territooriumile, kuid erinevate teadmiste osas.

Kuuendaks, siin on analüüsitud ainult küsimise ja infoandmise vahekorda. Lisaks kasutatakse kas-küsimusi nt infosoovide (nt telefoninumbrite küsimine) ja tegevussoovide (nt soola andmine) sõnastamiseks (vt Curl, Drew 2008; Hennoste jt 2009b). Kõiki neid tehakse nt imperatiiviga (ütle mulle // anna soola), väitvormiga ( $x x$ number // sool) ning küsivormiga (kas te ei ütleks // kas te ei annaks soola). Vestlusanalüüsis on soovide küsivormi kasutust seotud küsija prognoosiga, et vastav info ei ole saadaval, või sellega, et ta ei oska ise oma soovi täpselt sõnastada. Selliselt võime öelda, et küsimuse vorm väljendab suuremat ebakindlust info saadavuses. Nii näeme, et ka seda saab analüüsida episteemilise staatuse ja hoiaku terminites. Siin pole aga tegu mitte erinevustega info sisu tõlgendamisel, vaid info saadavuse tõlgendamisel.

Artikkel on valminud Euroopa Regionaalarengufondi Eesti Arvutiteaduse Tippkeskuse (projekt SF0180078s08), projektide „Suulise eesti keele audiovisuaalse suhtluskorpuse kogumine ja päringusüsteemi arendamine” (EKT8) ja „Eestikeelse spontaanse dialoogi struktuuri loomise keelelised vahendid” (ETF-i grant 8558) toetusel. Tänan Eva Liina Asu-Garciat, Paul Drew'd, Kirsi Laanesood ja Andriela Rääbist, kellega siinsete mõtete arutamine aitas lugu paremaks teha. 


\section{Kirjandus}

A s u, Eva Liina 2002. Downtrends in Different Types of Question in Estonian. Proceedings of the Speech Prosody 2002 conference. Toim B. Bel, I. Marlien. Aix-en-Provence: Laboratoire Parole et Langage, lk 143-146.

A s u, Eva Liina, N o l a n, Francis 2003. Testing a Model of Estonian Intonation. - Proceedings of the 15th International Congress of Phonetic Sciences. Toim M. J. Sole, D. Recasens, J. Romero. Barcelona: Futugraphic, lk 1249-1252.

C u r l, Traci S., D rew, Paul 2008. Contingency and Action. A Comparison of Two Forms of Requesting. - Research on Language and Social Interaction, kd 41, lk 129-153.

Engle rt, Christina 2010. Questions and Responses in Dutch Conversations. Journal of Pragmatics, kd 42, lk 2666-2684.

Go od win, Charles 1979. The Interactive Construction of a Sentence in Natural Conversation. Everyday Language: Studies in Ethnomethodology. Toim G. Psathas. New York: Irvington Publishers, lk 97-121.

$\mathrm{H}$ a a n, Judith 2001. Speaking of Questions. An Exploration of Dutch Question Intonation. Utrecht: Netherlands Graduate School of Linguistics.

$\mathrm{H}$ e i $\mathrm{n}$ e $\mathrm{m}$ a $\mathrm{n}$ n, Trine 2009. Two Answers to Inapposite Inquiries. - Conversation Analysis: Comparative Perspectives. Toim J. Sidnell. Cambridge: Cambridge University Press, lk 159-186.

H e i n e m a n n, Trine 2010. The Question-Response System of Danish. - Journal of Pragmatics, kd 42, lk 2703-2725.

$\mathrm{H}$ e n n o s t e, Tiit 2008. Sõnakatkestusega algavate lausesisese reformuleerimise tüübid eestikeelses vestluses. - Uralica Helsingiensia 1. Lähivertailuja 18. Toim H. Metslang, R. Grünthal. Helsinki, lk 31-53.

H e n n o s t e, Tiit 2011. Suuline süntaks ehk dialoogi protsessilausete grammatika. - Oma Keel, nr 2, lk 11-16.

Hennoste, Tiit, Rääbis, Andriela 2004. Dialoogiaktid eesti infodialoogides. Tüpoloogia ja analüüs. Tartu: Tartu Ülikooli Kirjastus.

Hen n o s te, Tiit, G e r a s s i m e n o, Olga, Ka s t e r p a l u, Riina, Ko it, Mare, R ä äb i s, Andriela, S tr a n d s o n, Krista 2009a. Küsimused eestikeelses infodialoogis I. Küsimuste vorm. - Keel ja Kirjandus, nr 5, lk 341-359.

Hennos te, Tiit, Ger a s s i m e n k o, Olga, Ka st e r p a l u, Riina, Ko it, Mare, R ä ä b i s, Andriela, S tr a n d s o n, Krista 2009b. Suulise eesti keele korpus ja inimese suhtlus arvutiga. Eesti Rakenduslingvistika Ühingu aastaraamat V. Toim H. Metslang, M. Langemets, M.-M. Sepper, R. Argus. Tallinn: Eesti Keele Sihtasutus, lk 111-130.

H e n n o s t e, Tiit, R ä äb i s, Andriela, L a a n e s o o, Kirsi (ilmumas). Küsimused eestikeelses infodialoogis II. Küsimused ja tegevused. - Keel ja Kirjandus, ilmumas.

Herita ge, John 2010. Questioning in Medicine. - „Why Do You Ask?” The Function of Questions in Institutional Discourse. Toim A. F. Freed, S. Ehrlich. Oxford: Oxford UP, lk 42-68.

$\mathrm{H}$ e r i t a g e, John 2012a. Epistemic in Action. Action Formation and Territories of Knowledge. - Research on Language and Social Interaction, kd 45, lk 1-29.

$\mathrm{H}$ e r i t a g e, John 2012b. The Epistemic Engine. Sequence Organization and Territories of Knowledge. - Research on Language and Social Interaction, kd 45, lk 30-52. 
H e r i t a g e, John (ilmumas). Epistemics. - The Handbook of Conversation Analysis. Toim J. Sidnell, T. Stivers. Boston: Wiley-Blackwell.

H e r i t a g e, John, R a y m o n d, Geoffrey 2005. The Terms of Agreement. Indexing Epistemic Authority and Subordination in Talk-in-Interaction. - Social Psychology Quarterly, kd 68, lk 15-38.

K a m i o, Akio 1997. Territory of Information. Amsterdam: John Benjamins.

K e e valli k, Leelo 1999. Informatsioonikäsitluse partikkel ahah telefonivestlustes. - Emakeele Seltsi aastaraamat 43 (1997). Tartu: Emakeele Selts, lk 34-56.

Ke e vallik, Leelo 2009. Üldküsimuse lihtvastuse funktsioonid. - Keel ja Kirjandus, nr 1, lk 33-53.

L a b o v, William, F a n s h e l, David 1977. Therapeutic Discourse. Psychotherapy as Conversation. New York: Academic Press.

P o m e r a n t z, Anita 1980. Telling My Side. 'Limited Access' as a 'Fishing' Device. - Sociological Inquiry, kd 50, lk 186-198.

$\mathrm{R}$ a y m o n d, Geoffrey, H e r it a g e, John 2006. The Epistemics of Social Relations. Owning Grandchildren. - Language in Society, kd 35, lk 677-705.

R o s s a n o, Federico 2010. Questioning and Responding in Italian. - Journal of Pragmatics, kd 42, lk 2756-2771.

Sid ne ll, Jack 2012. Declaratives, Questioning, Defeasibility. - Research on Language and Social Interaction, kd 45, lk 53-60.

S o r j o n e n, Marja-Leena 2001. Simple Answers to Polar Questions. The Case of Finnish. - Studies in Interactional Linguistics. Toim E. Couper-Kuhlen, M. Selting. Amsterdam: John Benjamins, lk 405-431.

S t e e n sig, Jakob, Drew, Paul 2008. Introduction. Questioning and Affiliation/ Disaffiliation in Interaction. - Discourse Studies, kd 10, lk 5-15.

S tive r s, Tanya 2010. An Overview of the Question-Response System in American English Conversation. - Journal of Pragmatics, kd 42, lk 2772-2781.

Stivers, Tanya, Enfield, Nick J. 2010. A Coding Scheme for Question-Response Sequences in Conversation. - Journal of Pragmatics, kd 42, lk 2620-2626.

\section{Transkriptsioonimärgid}

\begin{tabular}{|c|c|}
\hline & langev intonatsioon, lausungi lõpp \\
\hline & tõusev intonatsioon \\
\hline & poollangev intonatsioon \\
\hline (.) & mikropaus: 0.2 sekundit või lühem \\
\hline$(0.8)$ & mõõdetud paus sekundites \\
\hline & graavis, rõhutatud sõna \\
\hline - & sõna poolelijäämine \\
\hline : & hääliku venitamine \\
\hline. $\mathrm{hh}$ & häälekas sissehingamine \\
\hline$=$ & otsarääkimine \\
\hline[ & pealerääkimise algus \\
\hline ] & pealerääkimise lõpp \\
\hline$\$ \ldots . . \$$ & naerva häälega öeldud sõna või lõik \\
\hline @....@ & hääletooni või hääle kvaliteedi muutumine \\
\hline$* \ldots . . . *$ & vaiksem jutt \\
\hline$\{--\}$ & transkribeerimatu lõik \\
\hline$(())$ & transkribeerija kommentaar \\
\hline // & vooruvahetus ühes reas esitatud näidetes \\
\hline
\end{tabular}




\section{The Form of Asking Questions, Epistemic Status and Epistemic Stance}

Keywords: oral dialogue, questions, epistemic status, epistemic stance, conversation analysis

One of the central problems in the analysis of asking questions is how the tools of asking (interrogative utterances in various forms and declarative questions pronounced with various intonations) might relate to asking questions as a social action.

The model and approach underlying the present study come from John Heritage, US sociologist and conversation analyst. Heritage trusts that in a general case the interactants have a different access to the topic of current conversation. This difference is termed as epistemic status. Heritage argues that when a question is formed, epistemic status prevails over morphosyntax and intonation, ultimately determining whether the given utterance will be interpreted as one of asking or giving information. Examples of yes/no questions used in conversation are used as proof of this argument. Another important concept introduced by Heritage is epistemic stance, which marks the moment's situation in the informational balance, which changes from turn to turn, being controlled by means of turn/utterance structure (e.g. Are you married? and You're married, aren't you?).

The present article has two purposes: first, to demonstrate how the epistemic status of the interactants appears as a metagrammatical factor in Estonian communication, and second, to make a list of the formal tools available for expressing the epistemic stance in Estonian yes/no questions and show that the speaker will choose precisely such tools that match his/her epistemic stance in that moment's situation.

The methods used in the reported study are conversation analysis and quantitative analysis. The examples presented come from Tartu University Corpus of Spoken Estonian.

Tiit Hennoste (b. 1953), MA, University of Tartu, Laboratory of Spoken and Computer Mediated Communication, research fellow, tiit.hennoste@ut.ee 